\title{
The breaching experiment. Donald Trump and the normative foundations of democracy
}

\author{
Andreas Schedler
}

Published online: 9 December 2019

(C) The Author(s) 2019. corrected publication 2019

\begin{abstract}
Is US president Donald Trump a threat to democracy? Alerting against his manifold transgressions of democratic norms, many comparative political scientists have thought so. Their practical worries, however, have been inconsistent with prevalent theories of democratic stability. As careful examination shows, his main democratic norm violations have been discursive, and they have revealed him to be, not an ideological enemy of democracy, but a self-centered actor without deep democratic commitments. None of this should ring democratic alarm bells. But it does. As I suggest, Donald Trump has been conducting a kind of sociological "breaching experiment" on the political science community which has exposed a remarkable divergence between our main theories of democratic stability (which focus on structures, political behavior, and self-interest) and our tacit convictions (about the causal relevance of actors, political language, and normative commitments).
\end{abstract}

Keywords Comparative politics · Democratic stability · Donald Trump · Breaching experiments $\cdot$ Democratic norms $\cdot$ Political language 


\section{Das Krisenexperiment. Donald Trump und die normativen Grundlagen der Demokratie}

Zusammenfassung Stellt Donald Trump eine existentielle Bedrohung für die USDemokratie dar? Im Lichte der vielfältigen demokratischen Normverstöße des Präsidenten neigt die vergleichende Politikwissenschaft dazu, diese Frage zu bejahen. Diese Antwort ist jedoch schwer vereinbar mit vorherrschenden Theorien demokratischer Stabilität. Wie sich bei sorgfältiger Überprüfung erweist, sind Donald Trumps demokratische Normverletzungen im Wesentlichen diskursiv, und sie enthüllen ihn nicht als antidemokratischen Ideologen, sondern als eigennützigen Akteur ohne tiefe demokratische Überzeugungen. Nichts davon sollte uns beunruhigen, tut es aber offenbar. Donald Trump hat, so das Kernargument dieses Essays, die vergleichende Politikwissenschaft gleichsam einem soziologischen „Krisenexperiment“ unterworfen, das eine tiefe Kluft sichtbar gemacht hat zwischen unseren etablierten Theorien und unseren impliziten, kausalen und normativen Grundannahmen über demokratische Stabilitätsbedingungen.

Schlüsselwörter Vergleichende Politikwissenschaft · Demokratische Stabilität · Donald Trump · Breaching experiments · Democratic norms · Political language

\section{Introduction}

Donald Trump has done political science a great service. He has pushed the United States out of the parochialism of American politics into the realm of comparative politics. And vice versa, he has made comparative scholars veer towards the US. Since he won, first the Republican nomination and then the presidency, US democracy has faced a problem that was thought to be exclusive to democracies in developing countries: public concerns about its survival. If democracies are consolidated when they can be expected "to last well into the future" (Valenzuela 1992, p. 70), the ascent of Donald Trump to the US presidency has put an end to democratic consolidation. In US public debate, the stability of democracy is no longer taken for granted. All of a sudden, the country has entered the universe of fragile democracies and turned into a crucial case in the comparative study of democratic persistence. ${ }^{1}$

Strangely, though, the way we are looking at democratic politics when we discuss Donald Trump and the ways we have been looking at democratic politics in the comparative study of political regimes are startlingly dissonant. Many of our democratic worries about Donald Trump seem to arise from factors that do not bother us in the comparative study of democracy: his unconstrained discourse, his violation of linguistic norms, and his programmatic amorality. As I contend, Donald Trump provokes democratic anxieties which we had ignored in our comparative research because he violates tacit cognitive, normative, and causal assumptions which we had taken for granted. By challenging these implicit assumptions, Donald Trump

\footnotetext{
1 For broader reflections on the relations between the subfields of American and comparative politics, see Finkel et al. (2019) and Kuo (2019).
} 
has pushed them into the open. In this sense, his normative transgressions have worked in a way akin to sociological "breaching experiments" which unveil tacit expectations by breaking them.

This essay is primarily an exercise in disciplinary self-reflection. It strives to make sense of the way we have been responding to Donald Trump's unsettling political career. The "we" I keep referring to is somewhat fluid. Its expansive version includes us, practitioners of comparative politics; its more narrow version refers to us, students of political regime change. My central claim is one of analytical incongruence. As I contend, our perceptions of the threats Trump poses to US democracy do not match our main theories of democratic instability. To establish this claim, I dedicate a fair part of this essay to assessing the nature and severity of Donald Trump's democratic norm transgressions, since they delineate our precise object of both research and anxiety.

I begin by sketching the global debate on "democratic backsliding" whose scope and urgency has dramatically increased after Donald Trump's appearance on the political stage. I then lay out three features of contemporary research on democratic stability which are strangely inconsistent with our democratic anxieties about the 45th US president: its emphasis on structure, democratic "high crimes", and the stabilizing force of self-interest. I go on to explain the basic logic of the "breaching experiments" introduced by ethnomethodologist Harold Garfinkel in the early 1960s. In the main section of the paper, I describe the fundamentals of Donald Trump's practical breaching experiment by drawing a preliminary balance sheet of his compliance with fundamental democratic norms, which allows me to identify the demonstrative value of his breaches: they are forcing us to recognize the relevance of political actors, political language, and normative commitments.

\section{Democratic anxieties}

Over the past years, concerns about worldwide "democratic backsliding" have been spreading and deepening in academic, political, and diplomatic circles. ${ }^{2}$ Even though the New York think tank Freedom House laments more than a decade of steady "decline in global freedom" (Freedom House 2018), until now instances of democratic progress and regression have largely offset each other (see e.g. Varieties of Democracy 2017). The worldwide sense of democratic crisis seems to derive less from a clear pattern of democratic retrocession than from the absence of a clear pattern. We have seen transitions from democracy to authoritarianism taking place in highly diverse circumstances, in relatively poor countries (such as Nicaragua and Bolivia) as well as in relatively rich ones (such as Thailand and Venezuela). And they have been driven by the manipulation of a wide range of societal cleavages, such as class conflict (as in Venezuela and Thailand), religious conflict (as in Egypt and Turkey), or national self-assertion (as in Russia and Hungary) (see e.g. Bermeo 2016; Dia-

\footnotetext{
2 See e.g. Bermeo (2016), Cheibub (2014, pp. 8-9), Diamond (2015, pp. 144-147), Waldner and Lust (2018), and Varieties of Democracy (2017).
} 
mond 2016; and Erdmann 2011). The disconcerting diversity of contexts and origins helps spreading the vague, alarming suspicion: "it can happen here" (Sunstein 2018).

In numerous instances, the "death" of new democracies has not been "rapid" but "slow". ${ }^{3}$ Military and executive coups continue to slay democratic regimes (see Tansey 2017). Yet, the modal transition from democratic rule today unfolds as a "slow and at times opaque" "process of successive authoritarian advances" (O'Donnell 1992, pp. 19, 33) in the hands of illiberal governments. Prime examples of contemporary leaders who have orchestrated gradual transitions from electoral democracy to electoral authoritarianism have been Russia's Vladimir Putin, Venezuela's Hugo Chávez, Turkey’s Recep Tayyip Erdoğan, and Hungary’s Viktor Orbán. ${ }^{4}$

Before Donald Trump's irruption into the US presidential election, concerns about the "global democratic recession" (Diamond 2015) had been largely confined to new democracies. Despite decades of debate about "the crisis of democracy" (see e.g. Merkel 2014), established democracies appeared to be essentially immune to their illiberal subversion. The US 2016 election has changed this overnight. It induced an instant radical shift of the democratic mood. Due to a surprising concatenation of contingent events, the unthinkable has become thinkable and the sense of democratic fragility has spread to "advanced" democracies. In a rare case of interdisciplinary convergence, politicians, journalists, historians, philosophers, psychologists, and political scientists alike have been warning that one of the world's oldest democracies might be sliding into authoritarian rule. ${ }^{5}$

\section{Disciplinary blinkers}

Comparative political science has been caught ill-prepared by democracy's renewed fragility. After the turn of the millennium, we had shifted much of our attention to study authoritarian regimes. ${ }^{6}$ Taking the stability of established democracies for granted (even while surveying their defects), we all but abandoned the study of consolidation in new democracies (see e.g. Cheibub 2014). Somewhat painfully, we now discover that the theoretical tools and empirical findings which we have accumulated in the comparative study of political regimes over decades are of little use for understanding the most common form of democratic regression today, that is, the stepwise subversion of democracy by illiberal governments (see also Waldner and Lust 2018). Arguably, their limited usefulness derives from their almost exclusive emphasis on probabilistic structural explanations, high-profile violations of democratic norms, and utilitarian sources of norm compliance.

\footnotetext{
3 The distinction was introduced by Guillermo O'Donnell (1992).

4 See e.g. Hale (2016, p. 24), Corrales (2011), Levitsky and Loxton (2013), Esen and Gumuscu (2016), Selçuk (2016), Batory (2016), and Magyar (2016).

5 Among many others, see Connolly (2017), Frum (2018), Galston (2018), Levitsky and Ziblatt (2018), Klaas (2017), Foa and Mounk (2017), Mounk (2018), Sunstein (2018), and Snyder (2017). For dissenting voices, see Moyn and Priestland (2017) and Mudde (2018).

${ }^{6}$ For critical overviews see Art (2012) and Pepinsky (2014).
} 


\subsection{The absence of actors}

Our body of past research on democratic continuity teaches us little about democratic backsliding because its main explanatory thrust lies on structural factors, such as economic wealth, social inequality, political institutions, mass culture, and the international environment. ${ }^{7}$ Enduring, structural causes, however, cannot account for short-term changes, such as processes of democratic subversion (see also Waldner and Lust 2018). Only political actors and their actions can.

Besides, structural explanations are probabilistic. They estimate average effects of contextual parameters and regime properties on the likelihood of regime change or survival. These explanations are never deterministic but leave room for contingencies. Even if we know, for example, that "economic explanation alone goes a long way" (Przeworski 2003, p. 129) in explaining democratic survival, it does not go all the way. The possibility of outliers, exceptions, and surprises always exists. That is, the possibility that deviant actors may disrupt structural equilibria always exists. As political scientists, it appears, we tend to deal with such remote possibilities in the bipolar fashion in which we as human beings tend to deal with low-probability outcomes: we either ignore or magnify them (see Kahneman 2011, Ch. 29). Donald Trump made us switch from one pole to the other.

\subsection{The narrowness of norms}

The classic definition of democratic consolidation as a situation in which democracy has turned into "the only game in town" (Linz and Stepan 1996, p. 5) describes a situation of universal rule compliance in which "all the actors in the polity [have] become habituated to the fact that political conflict will be resolved according to the established norms" (Linz and Stepan 1996, p. 5). They know, accept, and obey the fundamental rules of the democratic game, and expect others to do so as well. Yet which are those rules? What does democratic compliance entail?

Until recently, the literature on democratic instability focused its attention on those public and dramatic instances of democratic rule violation which account for the vast majority of "quick deaths" of democracy: military coups, executive takeovers, and armed rebellions (see e.g. Przeworski 2005; Svolik 2015a, b, p. 730). At the same time, the broad literature on "intermediate regime categories" (from "defective democracies" and "hybrid regimes" to "electoral authoritarianism") recognized that the forceful closure of representative institutions represents only one existential threat to democracy among many others. ${ }^{8}$ Political actors can damage democracy in countless ways below the level of open coups and rebellions. Given its interest in authoritarian governance, much of the hybrid-regime literature focused on what we may call "democratic capital crimes", that is, democratic norm breaches

\footnotetext{
7 See e.g. Gorokhovskaia (2017) and Merkel (2016). For explanations based on wealth, see, for example, Przeworski et al. (2000); on inequality, Acemoglu and Robinson (2006), and Boix (2003); on institutions, Linz (1990), Mainwaring (1993), Cheibub (2007), and Pérez-Liñán (2007); on culture, Diamond (1999), Inglehart and Welzel (2005), and Putnam (1994); and on international factors, Diamond et al. (2016).

8 Among many others, see Munck (2006), Merkel (2004), Levitsky and Way (2010), and Schedler (2013).
} 
that are "severe and systematic" enough to kill democracy. In the electoral realm, for instance, it studied transgressions such as repression, censorship, party bans, voter intimidation, or electoral fraud, which threaten the democratic spirit of multiparty elections. More recent research on "democratic backsliding" tends to replicate this focus on incisive norm violations that oblige us to raise the regime question: Is country X still a democracy? Or did the illiberal incumbent already push it into the realm of electoral authoritarianism? ${ }^{9}$ As I will argue, Donald Trump's transgressive behavior lies outside our standard catalogue of democratic offenses. It obliges us to broaden it, or rather, to recognize that it includes transgressions we had not held to be essential.

\subsection{The narrowness of motives}

If democracy requires actors to comply with its basic norms (however defined), what makes them do so? Which are the motivational foundations of compliance? Does democracy require democrats? Does it require normative commitments to democratic principles? Or can it work without them and rely on no more than actors' self-interested calculations of material benefit?

Even while recognizing the possibility of building "democracy without democrats" (see e.g. Salamé 1994), early studies of regime change placed actors' normative commitments to liberal democracy at the very center of their explanatory enterprises. Their central analytic distinction ran between the friends and enemies of democracy, between "democratic actors" committed to democracy, on the one side, and "authoritarian actors" hostile to it, on the other. In essence, the classic, multivolume project on democratic breakdown (edited by Linz and Stepan 1978) as well as the later collection on democratic transitions (edited by O'Donnell et al. 1986) explained political regime dynamics by the evolving power balance between these two categories of actors. For scholars of regime transitions, distinguishing between these polar camps (and the amorphous group in between) represented a central analytic challenge. ${ }^{10}$

Normative commitments to democracy continue to be an important subject matter in the comparative study of public opinion. ${ }^{11}$ Macro-level research, however, has largely abandoned the notion that political actors' normative commitments play a significant causal role in political regime dynamics. Prevalent theories of democratic stability discard the relevance of normative motives and assume democratic stability to be primarily grounded in material self-interest. They hold democracy to be sustainable when it constitutes a "self-enforcing equilibrium" which is "in nobody's interest to change" (O’Donnell 1994, p. 58). Assuming the universal primacy of self-interest, these theories conceive actor preferences for democracy or dictatorship

\footnotetext{
9 See, for example, Esen and Gumuscu (2016) on Recep Tayyip Erdoğan, Bogaards (2018) on Viktor Orbán, and Sánchez-Sibony (2017) on Rafael Correa.

10 The locus classicus is Linz's discussion of "loyal", "semi-loyal", and "disloyal" actors (1978, pp. 27-38).

11 For many others, see Bratton et al. (2005), Ferrín and Kriesi (2016), Pickel and Pickel (2016), Inglehart and Welzel (2005), and Schedler and Sarsfield (2007).
} 
as derivative of their underlying material interests (see e.g. Acemoglu and Robinson 2006; Boix 2003; Przeworski 2005; Svolik 2015a; Teorell 2010, p. 26).

The few "idealist" scholars who still insist on distinguishing between "democratic" and "authoritarian" actors on the basis of their "normative preferences" know that they are fighting an uphill battle. For instance, in their longitudinal study on Democracies and Dictatorships in Latin America, Scott Mainwaring and Aníbal Pérez-Liñán recognize that even the modest "idea that a value commitment to democracy could be a major asset for the durability of democracy is far from consensual" (Mainwaring and Pérez-Liñán 2013, L. 1233, emphasis added). Our responses to Donald Trump, however, seem to reveal a surprising consensus: we do not trust rational actors who lack "a value commitment to democracy".

\subsection{The puzzlement}

Given this state of the literature, our democratic anxieties about Donald Trump look puzzling. Despite the disciplinary emphasis we put on structures, basic norms, and self-interest, many of us, comparative scholars of political regimes, have responded with disbelief, shock, and alarm, both to the public behavior and the public persona of Donald Trump. Our systemic worries seem to ignore the weight of structures; they do not seem to arise from the types of transgressive behavior which we commonly associate with the demise of democracy; and they revolve around a politician who appears to pursue no more than his personal interest, rather than a transformative authoritarian program. How comes? Which are the sources of our anxieties? What is it in Donald Trump that awakes our democratic fears?

As I claim, our alarmed reactions within the political science community have been informative. They tell us that Donald Trump has been violating strong normative as well as causal assumptions about the foundations of liberal democracy which we had been embracing in a tacit manner, in contradiction with our explicit theories of democratic equilibria. In this sense, the 45th US president has subjected us to a political "breaching experiment" whose normative breaches have been exposing our hidden disciplinary assumptions about the normative bases of democracy.

\section{Breaching experiments}

In the 1960s, ethnomethodologist Harold Garfinkel directed his students to perform so-called "breaching experiments". These sociological experiments were designed to uncover the implicit cognitive or normative presuppositions that undergird ordinary social interactions. In classic examples, experimenters would pretend not to understand common-sensical expressions and ask for clarification. Or they would assume inappropriate social roles (such as acting like boarding students in their own homes) or attribute inappropriate social roles to others (such as treating costumers as salespersons) (see Garfinkel 1984, 2001). Unsurprisingly, such unexplained breaches of "the routine grounds of everyday activities" (Garfinkel 1984, p. 35) take subjects by surprise. The "nastiness of [their] surprise", Garfinkel posited, "should vary di- 
rectly" with the strength of the assumptions they hold about "normal" dynamics of social interaction $(2001$, p. 381).

As a matter of fact, the "unsuspecting subject[s]" (Garfinkel 2001, p. 385) of these experiments tended to respond with high emotional intensity to the breaches of trust they were confronted with. Garfinkel reported expressions of "astonishment, bewilderment, shock, anxiety, embarrassment, and anger" (p. 386). The experimental disruption of normality (under pretensions of normality) left some subjects, not just "bewildered" (p. 382) and "indignant" (p. 383), but badly "shaken" (p. 385). Their "suffering was dramatic and unrelieved" (p. 391). "No pains were spared" (p. 392). ${ }^{12}$

Breaching experiments continue to enjoy some popularity in contemporary sociology classes (see e.g. Braswell 2014) that direct their students to violate common rules of communication or interaction in order to uncover "hitherto undiscovered assumptions about commonsense reality" (McNall and Johnson 1975, p. 50). Their "breaching experiments" usually consist in doing either mildly funny or mildly irritating things "out of the normal", such as making music or noise in the quiet reading room of a public library, to record the consequent expressions of puzzlement or acts of resistance by the target audience. They aim at making explicit what we can leave implicit in our everyday interactions. As Garfinkel explained, they "must be thought of as demonstrations rather than as experiments" (2001, p. 381).

Though Donald Trump has been excelling in the Garfinkelian art form of "making trouble but not so much as to be jailed" (McNall and Johnson 1975, p. 50) we may safely assume that his multifaceted breaches of democratic expectations have not been designed to teach us lessons in democratic theory. If we wish to appreciate the didactic, demonstrative value they possess nonetheless, we need first to understand their precise nature. The US president is said to have broken "just about every basic rule of democratic politics" (Mounk 2018, p. 118). But what have been the exact contours of his transgressive acts and dispositions? Which exactly has been the political breaching experiment he has been performing on us?

Answering this question demands taking some analytic distance from ongoing debates on Donald Trump's breaches of democratic norms. In terms of their substantive focus, these debates have been quite disorderly, frequently mixing alleged violations of democratic and other types of norms, such as moral propriety or financial integrity (e.g. Frum 2018; and Klaas 2017). They often choose their objects of critique in inductive, associative ways. The president says and does things and his critics cry foul because they recognize some resemblance to actions undertaken by modern dictators ("the autocrat's playbook"). ${ }^{13}$ In evaluative terms, much of these debates have been conducted in a dichotomous, not to say Manichean, manner. Almost any transgression of democratic norms, regardless of their severity, has served to put Donald Trump into the category of the "elected autocrat" (Levitsky and Ziblatt 2018).

Here I propose a more "deductive", more systematic and comprehensive approach. Excluding all considerations that go beyond constitutive liberal-democratic norms, I review the US president's compliance with five sets of basic norms which

12 All citations in this paragraph are from Garfinkel (2001).

13 See Klaas (2017); also Chenoweth (2018), Frum (2018), and Moss (2018). 
the comparative literature holds to be largely uncontroversial (except for the last one): the support of democratic ideas and institutions, the renunciation of violence, the respect of electoral integrity, the respect of constitutional constraints, and linguistic accountability. With the help of illustrative comparisons from contemporary experiences of democratic subversion, I will strive to reach rough assessments of the severity of his normative breaches in these realms. Given the unending whirlwind of public controversies over his democratic transgressions, I will limit myself to his first two years in office. Besides, I will exclude all international considerations: the damage which external authoritarian interference invited, aided, or tolerated by Trump might have done to US democracy as well as the damage which the US president might have been inflicting on the democratic cause in other countries.

\section{The experiment}

As empirical scholars of comparative democracy, we sometimes must remind ourselves of the obvious: Democracy, the rule by the people, is a normative concept. Its core principles of equality and liberty stand against those that have ruled human societies during most of our collective existence: hierarchy and oppression. The set of modern representative institutions we describe as democratic strive to put those principles to practice: constitutional government, individual rights and liberties, the rule of law, competitive elections, representative legislatures, civil society, and mass media. Democracy requires those institutions. Without them, it cannot be said to exist. Yet, democracy also requires behavior which is consistent with its principles and institutions. It requires active compliance. Otherwise, its principles are empty rhetoric, its institutions empty shells. Which, then, are the basic behavioral demands that democracy puts on political actors ${ }^{14}$

\subsection{Democratic support}

The softest demand the democratic game places on its players is to support the game itself in public speech and writing. ${ }^{15}$ In its most narrow version, this implies the ideological demand to support democracy and reject its systemic alternatives. Yet, due to the formal or informal sanctions which most contemporary democracies put on anti-democratic speech, anti-democratic actors will seldom declare open hostility to democracy. Today, in the age of democracy, where everyone is supposed to profess at least lip service to liberal democratic values, even dictators have learnt to speak the language of democracy. Generic public declarations of democratic commitment have thus become worthless. They fail to distinguish democrats from anti-democrats.

\footnotetext{
14 In the following, I make two hugely simplifying assumptions: I treat democratic norms as absolute, which they are not (see Schedler 2019b). And I treat norm transgressions as transparent, which they are not either (see Schedler 2019a).

15 On the normative complexities of "democratic self-defense" against antidemocratic ideologies, see e.g. Kirshner (2014) and Issacharoff (2015, Ch. 5).
} 
In consequence, actors who are "structurally suspicious", be it because of their violent past (such as former authoritarian rulers and former guerrilla fighters) or their illiberal ideologies (such as communist parties and religious movements), face persistent suspicions that their public discourse and behavior is deceptive. In an analogous way to the subjects of oppression under authoritarianism, they are suspected of engaging in strategic "preference falsification" (Kuran 1995; Havel 1985). Almost invariably, critical debates about their democratic convictions revolve around distinctions like appearance vs. reality, mask vs. face, front stage vs. backstage (see e.g. Driessen 2012; Richards 2001).

Accordingly, we often demand that democratically suspicious actors do more than to profess general support for the fundamental rules, institutions, and principles of liberal democracy. We ask them to support the concrete rules and institutions that happen to govern their real existing democracy (see e.g. Booth and Seligson 2009; Higley and Gunther 1992). If they fail to do so, they do not reveal themselves as unequivocal enemies of democracy. But they do reinforce existing suspicions. They kindle the question whether they might eventually be willing to abandon, breach, or attack democratic institutions.

Such motivational suspicions have haunted debates on populism. Populist actors exploit the structural distance that separates citizens from their representatives in liberal democracy. They play a game of calculated ambiguity. While they present themselves as champions of democracy, they declare established democratic elites and institutions to be the source of all evil that befalls ordinary citizens. Given their ambivalent high-wire act between abstract support and concrete condemnation of democracy, the democratic commitments of populist actors have been subject to persistent controversy. Scholarly assessments span the whole range of possibilities. Populists have been analyzed as illiberal threats to democracy (Müller 2017; Weyland 2013), semi-democratic actors (Schedler 1996), democrats with exclusionary ethnic conceptions of the demos (Mudde 2010), democrats with alternative conceptions of democracy (Mounk 2018), and democrats with selective definitions of liberal democracy (Slater 2013; Rovira Kaltwasser 2012).

Since the early days of his presidential nomination campaign, Donald Trump has been identified as "the perfect populist" (Lind 2016). Surely, during his electoral campaign, he cherished to invoke "the people", "the forgotten ones", and portrayed existing democratic institutions as sites of treason and corruption. Yet, in office, he has clearly situated himself on one side of interparty competition. The central political conflict he mobilizes is not the populist cleavage (people vs. elite) but the partisan cleavage (Republicans vs. Democrats). Aside from playing the tunes of interparty polarization, he embraces a combination of ethnic and economic nationalism (older immigrants vs. more recent ones, ethnic Americans vs. all other nations) and has adjusted his self-description accordingly. ${ }^{16}$

Still, even though Donald Trump may not qualify as a populist, he does partake in the typical discursive ambiguities of populism. While various critics have labeled him a "fascist" or "aspirational fascist" (Beinhart 2018; Connolly 2017; and

16 "You know what I am? I'm a nationalist, O.K.? I'm a nationalist. Nationalist! Use that word! Use that word!" (cited in Baker 2018). 
Tucker 2016), he fully embraces the existing democratic order. He professes nothing but pride in the history of American democracy. He does not promise a fascist Führerstaat or the formal transformation of the US into a hereditary oligarchy. In contrast to other democratically ambiguous actors, he is not suspected either of dissimulating his authoritarian convictions. He has been accused of falsifying objective facts, but not his personal preferences. Even his critics see him as an open book. Due to his apparent lack of an ideological core and his "radical honesty" (Bruni 2018) about his own evolving thoughts and emotions, he has not been suspected of pursuing a hidden anti-democratic agenda.

Yet, while refraining from attacking democracy in the abstract, Donald Trump frequently criticizes specific democratic actors and institutions. Their appreciation seems to be strictly contingent on their conformity with his personal and political ambitions. If they serve his purposes, fine. If not, he showers them with contempt. This can be seen in his recurring rhetorical attacks against the media, judicial actors, and the electoral process. Much has been written about his hostile attitude towards critical news media, which are a central pillar of liberal democracy according to all democratic theory and "the enemy of the American people" according to Trump. ${ }^{17}$ Notoriously, the 45th US president has also been harshly dismissive of judicial actors he dislikes (be it courts, judges, prosecutors, the FBI, or the justice department) (see e.g. Baker 2017; Levitsky and Ziblatt 2018, pp. 178-179). In the closing weeks of the campaign, he started denouncing the presidential election as being "absolutely [] rigged", "one big fix", "one big, ugly lie" (Martin and Burns 2016), without offering even a hint of empirical evidence.

When political actors fail to pay honor to democratic institutions, the consequences are seldom direct. Their verbal attacks may induce others to reject and weaken these institutions, or else, to defend and strengthen them. In and by themselves, they do not impair institutional performance. Despite his rhetorical attacks on the press, Donald Trump has not been restricting freedom of opinion in practice. Despite his attacks on judicial actors, he has been heeding the limits they have set on his policies (see e.g. Posner 2018). In the first instance, the discursive denial of institutional respect is what it is: a discursive breach of democratic obligations. Its initial relevance is primarily diagnostic. It reveals the speaker's weak attachment to democratic values.

\subsection{The renunciation of violence}

The primary behavioral imperative of liberal democracy is its absolute ban on political violence. Violence is "the greatest enemy of democracy as we know it. [It] is anathema to its spirit and substance" (Keane 2004, p. 1). For the demos to speak and to be heard, arms must remain silent. Democracy prohibits the use of violence as an instrument of accessing state power (coups and rebellions), competing for state power (electoral and ethnic violence), exercising state power (political repression and the selective enforcement of law), influencing state policies (terrorism

17 See Grynbaum (2017). For a summary, see e.g. Klaas (2017, Ch. 2). 
and coercive corruption), ${ }^{18}$ and settling political conflicts among citizens (hitmen, paramilitary forces, lynching mobs).

Democracy, however, demands more from political actors than refraining from exercising violence in person. Democrats need to do everything in their power to prevent others from doing so. Political actors have a wide spectrum of possible strategies at their disposition through which they can induce others to commit political violence without bloodying their own hands. They can command, delegate, license, invite, encourage, condone, conceal, deny, belittle, and gloss over acts of political violence. Democrats must avoid any of this, unambiguously. They must show zero sympathy with the perpetrators of violence, regardless of who they are, and full solidarity with its victims, regardless of who they are. Their responsibility extends to their formal and informal agents as well as to their actual and potential allies. It also includes the obligation of recognizing their opponents as legitimate participants in the political process, rather than treating them as enemies who are legitimate targets of political violence.

Spanish political scientist Juan Linz, who saw the Spanish civil war break out at the age of ten, had been deeply troubled about ambiguities in the face of violence. "What", he asked in his seminal 1978 reflections on elite attitudes towards democracy, "would be an effective 'litmus test' of loyalty to a democratic regime? An obvious possibility is public commitment to legal means for gaining power, and rejection of the use of force. Ambiguities in such public commitments are certainly prima facie evidence of semiloyalty" (Linz 1978, p. 29). To exemplify, he cited the "willingness to encourage, tolerate, cover up, treat leniently, excuse, or justify the actions of other participants that go beyond the limits of peaceful, legitimate pattern of politics in a democracy" (Linz 1978, p. 32).

The democratic ban on political violence thus imposes a broad set of negative and positive obligations on political actors. How does the 45 th president of the US fare in this regard? The picture is mixed. In contrast to the global avant-garde of illiberal presidents, his personal involvement in domestic repressive violence has been close to zero. He has not conducted a wave of mass arrests against journalists, civil activists, politicians, and public officials, as Recep Tayyip Erdoğan has done after the 2016 coup attempt (see e.g. Kingsley 2017). He has not unleashed a campaign of extrajudicial killings against sellers and consumers of psychoactive drugs, as Rodrigo Duterte has done in the Philippines (see e.g. Berehulak 2016). Still, in his rhetoric, he has shown some of the ambiguities Juan Linz identified as symptoms of democratic semi-loyalty.

Above all, Donald Trump has been permissive towards the violence of ideologically proximate third parties. On numerous occasions, he has been seen as encouraging or condoning illegal violence. At campaign rallies, he invited his followers to "beat the crap" out of protesters and promised to cover their legal defense bills. Once, he obliquely suggested arm owners might recur to legitimate self-defense in case Hillary Clinton would restrict access to fire arms (indeed, in a context of deep partisan division over gun control, his advocacy of "gun rights" ensures that his political supporters control an immense and disproportionate arsenal of assault

18 The notion of "coercive corruption" was introduced by Lessing (2015). 
weapons-which they may never use for political purposes but can at any time). ${ }^{19}$ After his election victory, he hesitated to condemn attacks against Jewish institutions or deadly violence by neofascists in Charlottesville, Virginia. He deems the notion of holding police officers accountable for the use of lethal violence unpatriotic and has invited immigration officers to do their job without undue respect for human dignity ("please, don't be too nice"). ${ }^{20}$ Together with his trademark rhetorical aggressiveness against adversaries, Donald Trump's rhetorical ambiguities towards violent allies and agents are bound to breed consequences in the so-called real world. ${ }^{21}$

\subsection{Electoral integrity}

Since the end of the Cold War, the most common form of dictatorship are not military and single-party regimes anymore, but electoral autocracies which hold multiparty elections, yet subject them to severe and widespread manipulation (see e.g. Levitsky and Way 2010; Schedler 2013). Accordingly, as noted above, the most common form of democratic termination are not military coups anymore, but gradual, government-led transitions to electoral authoritarianism (see e.g. Bermeo 2016; Svolik 2017). Governments have a variegated "menu of manipulation" at their disposal which allows them to preserve the formal façade of competitive elections, while hollowing out their democratic substance (Schedler 2013, Ch. 3). In the transition to electoral authoritarianism he commandeered, Venezuela's Hugo Chávez, for example, deployed the entire arsenal. He rewrote the constitution to his liking; captured judges and electoral authorities; ruled by decree, through repressive laws, and the transgression of laws; colonized the state bureaucracy and civil society; stifled private media and created his own propaganda machine; harassed, banned, and prosecuted opposition parties, sacked their elected officials, or stripped them of formal authority (see e.g. Corrales 2015, 2011, Ch. 2).

What has Donald Trump done so far to threaten the integrity of the electoral process? During his campaign and after, he repeatedly denounced "the system" and "the election" to be "rigged" (see e.g. Martin and Burns 2016; Wines and Haberman 2018). He is right, of course. ${ }^{22}$ For a long time now, US democracy has suffered deep, structural damage from its radical openness to the influence of money (see e.g. Winters 2011) and the partisan manipulation of electoral rules (district boundaries and voter identification) (see e.g. Anderson 2018; McGann et al. 2016; Klaas 2017, Ch. 5; Schaffer 2008, Ch. 2). Donald Trump, though, has not been the creator of these structural flaws, only their beneficiary.

Has he further harmed the democratic integrity of American elections? Not that much, actually. Having lost the popular vote to Hillary Clinton, he kept complain-

\footnotetext{
19 According to 2017 survey data from the Pew Research Center, a "majority of gun owners (61\%) are Republicans or lean to the Republican Party [...], while only 20\% are Democrats or lean Democratic" (Parker 2017).

20 For a summary, see Klaas (2017, Ch. 6).

21 Various sources have reported a rise of violence against ethnic minorities during and after the 2016 presidential election (see e.g. Rushin and Edwards 2018; Levy 2018).

22 With similar irony, Krugman (2016).
} 
ing, as he had done during the campaign, about "serious voter fraud" (Shear and Haberman 2016), a rhetorical phenomenon that has eluded empirical documentation. He continued to play on the topic through his short-lived Presidential Advisory Commission on Election Integrity (see Wines and Haberman 2018) and took it up again after the 2018 midterm elections (see Thrush and Peters 2018). Yet, as in other spheres, the main harm done was discursive. Rather than undermining the integrity of elections, he has been undermining the credibility of elections. ${ }^{23}$

\subsection{Constitutional constraints}

In the 1990s, in early debates on the institutional foundations of democratic stability, Latin American countries were thought to inhabit the worst of all worlds. Combining presidential systems of separation of powers and fragmented multiparty systems, they seemed condemned to engender irresolvable confrontation between minoritarian presidents and legislative majorities, inviting the military to step in and play the arbiter (see e.g. Linz 1990; Mainwaring 1993). Subsequent empirical studies have qualified or shed doubt on "the perils of presidentialism" (see e.g. Negretto 2006; and Cheibub 2007), just as subsequent empirical events have increased confidence in the conflict-solving capacities of presidential democracies. Since the early 1990s, Latin American countries have solved recurrent "presidential crises", not through military intervention, but through the constitutional ousting of presidents who had lost the public trust (see e.g. Hochstetler 2006; Pérez-Liñán 2007).

In the light of preceding debates, it is not without irony that current dangers to democracy do not seem to arise from minority presidents who attack hostile legislatures, but from presidents who command legislative majorities and use them to redefine the rules of the political game. Juan Linz identified the tendency to produce "unified" rather than "divided government" as one of the core "virtues of parliamentarism" (Linz 1990). Today, executive control of the legislature constitutes the Archimedean point for hegemonic projects of "executive aggrandizement" (Bermeo 2016).

Putin, Chávez, Erdoğan, Orbán, and company have all followed the same basic script. Act one: they gain control over rule-making after winning legislative majorities. Act two: they extend their controlling powers to the final settlement of conflict by subjecting supreme courts to partisan control. Act three: once they are in control of the legal system (the content, implementation, and adjudication of law) they are (legally) free to colonize the entire state bureaucracy (including the management of elections) and to domesticate the media and civil society.

How does Donald Trump fit the picture? In his first two years in office, he enjoyed the relative comforts of "unified government". Even though Republican majorities in both chambers were rather slim, and the internal discipline of the party allowed for certain lapses, he used his legislative majorities to work towards effective partisan

\footnotetext{
23 See e.g. Malka and Lelkes (2017). On the public resonance of his complaints about voter fraud and media bias and their crisscrossing effects on voter turnout in the 2016 presidential elections, see Goidel et al. (2019).
} 
control of the judiciary. ${ }^{24}$ The contentious nominations of Neil Gorsuch and Brett Kavanaugh to the Supreme Court locked in a conservative majority at the peak of the judicial system. Democrats viewed them as part of a "Republican strategy to capture our judicial branch of government" (Senator Richard J. Durbin) (Stevenson 2017). The aggressive, sustained, and successful campaign by the president and his party to appoint ideologically proximate judges to federal appeals courts has been validating their fears (see e.g. Savage 2017; Hulse 2019). Of course, the degree of formal control which ruling parties and sitting presidents exercise over judicial appointments has always been a deep anomaly of US democracy. Their power to shape the ideological profile of the judicial system would be perceived with great apprehension in any other democracy. ${ }^{25}$

\subsection{Linguistic accountability}

Liberal democracy is not a measurement machine, a mechanism for registering the spontaneous, pre-reflexive preferences of citizens. It is a system for defining, debating, and deciding collective problems and conflicts within a community of free and equal citizens. Abjuring violence, abhorring violence, its core medium is language. Against the power of stones, swords, and guns, it poses the power of words (see e.g. Touraine 1988). It is only through our shared language that, "we, the people", know who we are, what we have in common, what divides us, what afflicts us, where we want to go. Liberal democracy requires elections, but the institutional core of popular sovereignty is not the electoral arena, but the public space that gives meaning to the electoral arena (see Habermas 1998). Its democratic quality hinges centrally on the integrity of public language, its responsible and accountable usage.

As users of language, we make claims - about the world, about others, about ourselves. As responsible language users we take these claims seriously. We accept the commitments they carry, and we accept being called to account for these commitments. Linguistic accountability involves the duty to clarify and explicate our claims (their meaning) in case of doubt, and to answer critical questions about their rationality: their truthfulness (when we make factual claims about objective realities), their appropriateness (when we articulate normative claims about social relations), their sincerity (when we put forward subjective claims about our inner world), and their consistency (with other things we say and do) (see e.g. Brandom 2000; Habermas 1984).

Linguistic irresponsibility comes in many faces. Donald Trump is the carrier of an extreme form. Numerous observers have noted traits of linguistic poverty, even pathology, in his public discourse, such as his simple syntax and limited vocabulary, his delight in transgressing rules of courtesy and decency, his fondness of personal insult, his habitual substitution of adjectives for arguments, the coarse nature of

\footnotetext{
24 According to Congressional Quarterly roll call data, the president's legislative support by his co-partisans was "the highest on record" (Amira et al. 2019, p. 766) since the late 1960s. "Trump received the support of $95.9 \%$ of his Republican co-partisans in the House and the support of $98.9 \%$ of his Republican co-partisans in the Senate" (Amira et al. 2019, p. 758).

25 In contemporary Poland, for instance (see European Commission 2017).
} 
his rhetoric, his impatience with caution and precision, his corresponding love for hyperbole and over-generalization, and last but not least, his general contempt for language ("just words"). Donald Trump has been called "a serial norm breaker" (Levitsky and Ziblatt 2018, pp. 146, 195). He surely is a serial breaker of linguistic norms. ${ }^{26}$

Within this context, the primary public concern about Donald Trump's political language, first as a candidate and then as president, has been his shallow commitment to truthfulness. While Bill Clinton faced impeachment charges over a single lie, Donald Trump has been generating an ever-growing list of lies, half-truths, and distortions of reality, creating "alternative facts" and "alternative lies" alike. ${ }^{27}$ Critics and adversaries alike have been describing him as a "compulsive" or "pathological liar" (Willingham 2016) and he has co-inspired a whole new genre of literature on democratic politics in "the post-truth era" (e.g. d'Ancona 2017).

Donald Trump not only generates an unending stream of arbitrary claims which are not (or only loosely) constrained by empirical realities or the rules of language. He fully commits himself to these claims with public displays of emotional certainty (often through the use of superlatives) and dismisses all pretensions of holding him accountable for them (often through repetition). His conception of truth is private and declarative: he tells the truth because he says so, his critics are liars, all fake, full point. He leaves no legitimate space for public argumentation. Herein lies the double core of his linguistic irresponsibility: in his demonstrable contempt for truth and his demonstrative rejection of linguistic accountability.

Linguistic responsibility may seem to belong to the luxury department of democratic quality. As a matter of fact, students of deliberative democracy have been analyzing it as such: as essential to the quality, but not to the very existence, of democracy (see e.g. Gutmann and Thompson 2004). Yet, Donald Trump made us realize that linguistic responsibility is just as essential to democratic conflict resolution as it is, for instance, to judicial conflict settlement. In judicial proceedings, judges are called upon to apply rules to facts as they are established before court. If they get the facts wrong, they get everything wrong. Without truth, no justice. Modern judicial systems accordingly treat false testimony not as a stylistic mishap but a criminal offense. Democracies protect the truthfulness of public debate through informal norms and practices of accountability rather than penal law. Still, their existential vulnerability to linguistic abuse is similar. Irresponsible and unaccountable speech dissolves the twin democratic assumption of a shared reality and a shared language. By turning politics into a cacophony of unintelligible voices, it destroys the public sphere, the virtual meeting point of the demos. Irresponsible speech is antidemocratic speech—not in substance, but in form. "If words fall into disrepair, what will substitute? They are all we have" (Judt 2010, L 1523).

\footnotetext{
26 Among many others, see Blow (2017), Connolly (2017, Ch. 1), Ott (2017), Thompson (2017). On linguistic traces of his "grandiose narcissism", see Ahmadian et al. (2017).

27 See, for instance, the Fact Checker's "ongoing database of the false and misleading claims made by President Trump since assuming office" by the Washington Post (https://washingtonpost.com/graphics/ politics/trump-claims-database, accessed December 18, 2018), the list of the president's "demonstrably false statements" compiled by the New York Times (Leonhardt and Thompson 2017), or "Donald Trump's File" at Politifact (https://www.politifact.com/personalities/donald-trump, accessed December 18, 2018).
} 


\section{The revelation}

Harold Garfinkel introduced his sociological breaching experiments as "a means of eliciting social order through the disruption of taken-for-granted realities" (Gregory 1982, p. 49). Their core purpose lies in the "'rediscovery' of common sense" (Garfinkel 1984, p. 75). By violating hidden assumptions of ordinary social interaction, these transgressive experiments intend to render them visible. The anxiety produced by the disappointment of tacit expectations is meant to serve an epistemic purpose: making them explicit. ${ }^{28}$ Now, which are our hidden assumptions about the democratic order that Donald Trump's political breaching experiment have been unveiling? As I wish to suggest, our anxious responses to his transgressions have been revealing implicit assumptions we hold about the power of individual actors, behavioral norms that constrain public speech, and normative motives that constrain political actors.

\subsection{The weight of actors}

Even while Donald Trump's ascent to power has provoked intense debates about the threats he might pose to democracy, the United States of America are, of course, an entirely improbable case of democratic breakdown. The country scores high on almost all the structural and institutional characteristics which the comparative literature has identified as foundations of democratic stability, such as societal modernity and economic affluence, a broad middle class and a vibrant civil society, a prodemocratic citizenry, a strong judicial system, high regulatory and extractive state capacities, the protection of wealth from redistributive pressures, multiple experiences of alternation in power, high party-systemic institutionalization, strong vertical and horizontal divisions of power, and geographical proximity to the West.

Considering that our established theories of democratic consolidation lead us to expect US democracy "to last forever" (Przeworski and Limongi 1997, p. 165), what do fears about its subversion by Donald Trump tell us? Are they signs of scientific ignorance? Or expressions of partisan hysteria (see e.g. Moyn and Priestland 2017)? I believe they are neither. In fact, I hold them to be entirely rational and compatible with our scientific findings.

Political science is a craft of probabilistic inferences. It strives to discern empirical regularities, estimate average effects, and predict probable outcomes. Politics, by contrast, ineluctably contains possibilistic streaks. While it needs to calculate probable outcomes, it cannot ignore possible ones. It cannot ignore the fact that improbable events may happen after all. In relation to desirable events, politics is the art of the possible (and who could better testify to that point than Donald Trump himself). Its imagined capacity to make possible the impossible, or more modestly,

\footnotetext{
28 In the breaching experiments which university professors assign in their sociology classes, the students who carry them out often produce high levels of anxiety and anger among their target audiences. In addition, they themselves experience high levels of discomfort and distress (see Gregory 1982). Donald Trump, by contrast, does not show any signs of "experimenter anxiety" (Gregory 1982, p. 49). Quite to the contrary, he seems to enjoy the pleasures of defiance and transgression.
} 
to make the improbable come true, is a recurrent source of hope. In relation to undesirable events, politics is the art of the impossible. In the face of grave threats, it needs to take "all necessary precautions" to preempt their occurrence.

In the US (as well as elsewhere), fears about democratic subversion are not probabilistic, but possibilistic. The haunting question about authoritarianism in the US has always been (as in Lewis 2014 or Sunstein 2018): Can it happen here? Rather than: Will it happen here? Such concerns are expressions, not of irrationality, but of rational caution in the face of possible catastrophes. The odds that a democratic head of government will be able to destroy a complex, affluent, long-lived democracy are small. Still, they are arguably larger than zero. Democratic citizens are supposed to be vigilant and risk-averse towards potential threats to their rights and liberties. Rather than relaxing in the face of unlikely catastrophes, they must strive to discern and to preempt them. As our Trumpian anxieties reveal, we, probabilistic political scientists, do the same.

In our role of democratic citizens, we too embrace what cognitive psychologists call the "possibility effect", which is, our human tendency to either ignore or overweight improbable outcomes (see Kahneman 2011, Ch. 29). For long, in so-called advanced democracies, we thought that we could dismiss any residual risks to their equilibria. Now, they make us panic. And plausibly so. In the face of existential threats whose (low) probabilities are not fixed by "nature" but contingent on our own behavior, their "overweighting" is not an expression of "bounded rationality" (Kahneman 2011, Ch. 29) but political prudence. Adopting such a "possibilistic" viewpoint, is not unscientific, although it does rest on a form of reasoning we are not accustomed to: the logic of "possibilism" (Hirschman 1986; Lepenies 2008).

\subsection{The weight of words}

How much damage have Donald Trump's democratic transgressions inflicted on US democracy so far? Although academic experts tend to see "a sharp decline" in the quality of US democracy under Donald Trump (Carey et al. 2019, p. 701), none of his normative transgressions amounted to a major catastrophe. He has not suspended civil liberties, called in the military, organized anti-Mexican riots, or set up prison camps for Muslims. Despite some scratches on its surface, and some beneath, US democracy is still standing, vibrant with pluralism and activism. With all its structural defects, it has not been consumed by the fury of Donald Trump's national narcissism. Many observers have interpreted this as a testimony to the enduring strength of democratic institutions: "The system worked" (Kristof 2018).

Given the paramount importance of impartial state institutions for democracy (see e.g. Lapuente and Rothstein 2014), the president's judicial appointment policies risk deleterious long-term effects on democracy. The Republican Party's success in enlarging the conservative majority on the Supreme Court and its sweeping campaign to shift the composition of federal appeal courts involve a creeping colonization of the judicial system. Although they have breached longstanding informal rules, these policies have remained within the bounds of the law, that is, within the bounds of a legal system that permits its own partisan capture. The expected political con- 
sequences are transparent: a more conservative bench is more likely to shield the president and his party from judicial accountability.

Otherwise, though, the 45th US president's most severe democratic norm violations during his first two years in office have been discursive. This applies to his contempt towards democratic actors and institutions that threaten to thwart his ambitions; his recurrent ambiguities towards acts of political violence by ideologically proximate actors; his partisan support for unfair electoral boundaries and exclusionary voter registration laws, and his prodigious linguistic irresponsibility. Yet, as philosophers of language know, speech acts are acts, too. Arguably, they are the most important category of political acts in democratic politics. From the viewpoint of comparative regime studies, though, our sensation of alarm in the face of Donald Trump's discursive norm transgressions looks puzzling, considering the relative neglect of such transgressions in our discipline.

In the comparative literature on political regimes, we have been studying a broad set of democratic norm violations, often on the basis of longitudinal cross-national datasets. Some of our datasets capture dramatic events and processes, like military coups, civil wars, acts of terrorism, riots, and electoral violence. Others provide annual assessments on vital dimensions of democratic quality, such as state repression, media freedom, electoral integrity, the rule of law, judicial independence, and corruption. ${ }^{29}$ None, however, captures what has been igniting our worst fears in "the dangerous case of Donald Trump" (Lee 2017): his public discourse. The realm of public speech has been below the radar of comparative regime studies.

In general, in comparative politics, we have been reluctant to take public speech seriously. We have tended to regard it as a both illegitimate and unreliable type of empirical evidence. Given the symbolic nature of language, we often set speech in sharp contrast with "observable behavior" and thus exclude it from the realm of legitimate evidence. In addition, since speakers may be insincere and words deceptive, we habitually conclude that we should ignore what people say (their political discourse) and look exclusively at what they do (their political practice) (see e.g. King et al. 1994, p. 112; Przeworski 2010, L 278; and Rathburn 2008).

Both grounds for excluding political discourse from empirical analysis do not withstand scrutiny. (a) The notion that public discourse is "non-behavioral" overlooks that it belongs to the most important category of human action: speech acts (see e.g. Austin 1962; Searle 1969); and the notion that its symbolic nature renders it dependent on interpretation and thus "non-observable" overlooks the intrinsically interpretative nature of all social observation. ${ }^{30}$ (b) The potential of human speech for deception and dissimulation is undeniable. Yet it has its counterpart in our human capacity of discerning inconsistency and insincerity. Donald Trump nicely illustrates the point: none of his critics have been accepting his discourse naively. Quite to the contrary, every word he utters in public and every sentence he tweets are subject to intense scrutiny.

\footnotetext{
29 The QoG Standard Dataset by the Quality of Government Institute at the University of Gothenburg integrates data from over 100 sources (https://qog.pol.gu.se/data/datadownloads/qogstandarddata).

30 A locus classicus is Winch (1958).
} 
Of course, "qualitative" or "interpretative" traditions of political research have no methodological reservations towards the study of language. Quite to the contrary, they place political language at the very center of their analysis. ${ }^{31}$ And so do studies of political communication and electoral campaigns (for an overview, see Korte and Regge 2016). Furthermore, in recent years, due to both the electronic availability of huge amounts of text and technological progress in automated text analysis, more and more political scientists from the "quantitative" or "positive" camp, too, have been embracing "text as data" (see e.g. Grimmer and Stewart 2013). Our comparative research of regime dynamics, however, had been "speechless" until very recently. What political actors said in public had no explanatory value within our common analytical perspectives. We treated it as Trump would have: "It's just words". ${ }^{32}$ It was only through the radical discursive disinhibition of figures like Hugo Chávez and Donald Trump that we have been "bringing language back in" to our democratic threat analyses, for instance, in emergent comparative research on populist communication (e.g. Aalberg et al. 2017; Hawkins and Kaltwasser 2017) and political polarization (e.g. McCoy et al. 2018).

\subsection{The weight of normative motives}

Outside the community of his followers, Donald Trump has been provoking anxiety and irritation by the things he says and does, but perhaps even more so, by the person he reveals himself to be through the things he says and does. For us, political scientists, such emotional reactions are puzzling. Why should we be anxious, why get irritated, by the personal characteristics an individual decision-maker displays? In our theories of politics, we commonly assume actors to be homogenous. We expect them to be driven by similar motives, view the world in similar ways, and behave in similar manner under similar conditions. By assuming that they are all equal in their basic desires and beliefs we can explain their decisions as products of objective circumstances, rather than personal traits (see e.g. Brennan 1996).

In the academic world of comparative politics, the analytic assumption of actor homogeneity is commonsensical. In the so-called real world of politics, by contrast, it is almost unintelligible. Observers as well as practitioners of politics tend to assume that few things matter more to political outcomes than the identity of individual decision-makers. To them, political actors are not fungible. To the contrary, they appear as unique carriers of political world views, moral commitments, intellectual capacities, emotional intelligence, and so forth (see also Schedler 2007, pp. 59-61). Only antipolitical populists and their followers who condemn "the political class" tout court as a cartel of self-serving "traitors of the people" share the idea of homogenous actors, at least at the level of established political elites.

Under the assumption of homogenous actors, the entire debate on Donald Trump would make no sense at all, as it is premised on the opposite idea of radical actor heterogeneity. Neither his followers nor his detractors treat Donald Trump as an actor "like anybody else". His irruption into politics has brought back the notion

\footnotetext{
31 For a broad overview of perspectives and applications, see Wodak and Forchtner (2018).

32 Cited in Twohey and Barbaro (2016).
} 
that qualitative differences among political actors may serve as prime explanatory factors of political action.

Donald Trump's distinctive personal traits have been subject to intense debate. With certain obsessiveness, we have been talking about cognitive or emotional questions like presidential attention spans, impulse control, and tolerance to criticism. With psychiatrists weighting into the debate, the 45th president of the United States has been challenging our social scientific standard assumption of actor rationality (in the elementary sense of mental sanity) (see e.g. Cruz and Buser 2016; Lee 2017). With respect to his relationship to democracy, though, our core concerns have been normative. Donald Trump's ongoing "breaching experiment" has pushed us to rediscover an explanatory variable which we had largely abandoned in the comparative study of political regimes, namely, variations in political actors' normative commitments to liberal-democratic values.

What does Donald Trump's record of democratic norm transgressions reveal about the strength of his democratic commitments? In terms of Juan Linz' classic tripartite distinction, it seems plausible to locate him in the intermediate category of a "semiloyal" actor who would not work to destroy democracy (as "disloyal" actors would) nor rise to defend it either (as "loyal" actors would). He seems to lack a normative commitment to liberal-democratic norms as well as an ideological commitment to authoritarian alternatives. As a matter of fact, he seems to lack any discernible normative commitments. His explicit political maxim lies in the maximization of personal, partisan, and national self-interest. Amorality is his very program. Neither "loyal" friend nor "disloyal" enemy of democracy, he is, above all, a rational man. $\mathrm{He}$ is the personification of our homogenous, utility-maximizing, rational actor.

So, here we have a puber economicus, a faithful disciple of our standard model of economic rationality, occupying the Oval Office ... and instead of watching events unfold with analytical detachment, we are alarmed! While countervailing forces have prevented him from transgressing his presidential powers, he has been deploying them in unrestrained, uncompromising fashion. Analytically, his lack of selfrestraint, his open rejection of democratic fair play and civility, his ruthless pursuit of partisan advantage, seem unremarkable. They are simple displays of rational selfinterest. Yet, comparative scholars have seen them as dangerous breaches of informal norms, as "a supercharged version of constitutional hardball" that fractures the very foundations of democratic coexistence. ${ }^{33}$

Classic sociological breaching experiments slice the rational fabric of everyday interactions in order to render it visible. In these experiments, the irruption of irrationality unveils tacit, taken-for-granted structures of rationality, such as common knowledge or shared language. In the case of Donald Trump, by contrast, it is the irruption of rationality (in its narrow, instrumental sense) that unveils tacit, takenfor-granted assumptions about the causal relevance of normative commitments. His rational breaching experiment reveals hidden, normative sources of democratic equilibria. As it demonstrates, we do not fear for the future of democracy only when its ideological enemies conquer the halls of power. We also fear for its future when

33 See Mounk (2018, p. 118); also Levitsky and Ziblatt (2018, Ch. 5, 6). On the notion of "constitutional hardball", see Tushnet (2004). 
rational, utility-maximizing actors do so. Donald Trump's radical self-centeredness has led us to discover a new form of democratic anxiety, a new form of horror vacui: the dread of moral emptiness.

\section{Conclusion}

Through his cheerful breaches of democratic norms, Donald Trump has made comparative political science veer towards the United States. At the same time, by triggering democratic anxieties within the comparative community over behavior and attitudes we tend to ignore in our research, he has unveiled huge swaths of terra incognita at the very center of our discipline. By subjecting us to a practical "breaching experiment", he has drawn our attention to both causal and normative assumptions about democratic stability which we had kept out of our conscious disciplinary field of vision. In a certain manner, Donald Trump has pulled the rug under our theories of democratic equilibria. He has made us realize that in practice we do not trust three core assumptions that sustain our theories. We do not trust the structural foundations of democracy which we tend to focus on. We do not trust either the protective force we tend to ascribe to rational self-interest. Nor do we trust the methodological privilege we tend to grant to behavior over speech. Donald Trump, the macho economicus par excellence, has revealed the fragility of our confidence in probabilistic, structure-induced, interest-based democratic equilibria. And Donald Trump, the serial breaker of discursive norms, has unveiled the fragility of our indifference towards public speech. The disciplinary implications are almost revolutionary. They suggest a triple paradigmatic shift. If we wish to comprehend the disruptive potential of illiberal actors, we need a possibilistic turn in comparative politics. If we wish to comprehend the role of language in democratic equilibria, we need a linguistic turn in comparative politics. And if we wish to comprehend the role of normative commitments in democratic equilibria, we need a normative turn in comparative politics.

Acknowledgements I thank the Collegio Carlo Alberto in Turin, Italy, for supporting the elaboration of a first version of this essay. While, as usual, all responsibility remains mine, I am also grateful for critical comments by Veit Bader, André Banks, Philip Cook, Michael Coppedge, Mónica Ferrín, Maria Josua, Hans-Peter Kriesi, Hans-Joachim Lauth, Staffan Lindberg, Mariana Llanos, Glyn Morgan, Frederic C. Schaffer, Sofia Vera, Elizabeth Zechmeister, and the two anonymous ZfVP reviewers.

Open Access This article is distributed under the terms of the Creative Commons Attribution 4.0 International License (http://creativecommons.org/licenses/by/4.0/), which permits unrestricted use, distribution, and reproduction in any medium, provided you give appropriate credit to the original author(s) and the source, provide a link to the Creative Commons license, and indicate if changes were made.

\section{References}

Aalberg, Toril, Frank Esser, Carsten Reinemann, Jesper Strömbäck, and Claes H. de Vreese (eds.). 2017. Populist political communication in Europe. New York: Routledge.

Acemoglu, Daron, and James A. Robinson. 2006. Economic origins of dictatorship and democracy. Cambridge: Cambridge University Press. 
Ahmadian, Sara, Sara Azarshahi, and Delroy L. Paulhus. 2017. Explaining Donald Trump via communication style: grandiosity, informality, and dynamism. Personality and Individual Differences 107:49-53.

Amira, Karyn, Lauren Johnson, Deon McCray, and Jordan Ragusa. 2019. Adversaries or allies? Donald Trump's republican support in Congress. Perspectives on Politics 17(3):756-771.

Anderson, Carol. 2018. One person, no vote: how voter suppression is destroying our democracy. New York: Bloomsbury Publishing.

Art, David. 2012. What do we know about authoritarianism after ten years? Comparative Politics 44(3):351-373.

Austin, John L. 1962. How to do things with words. Oxford: Oxford University Press.

Baker, Peter. 2017. 'Very frustrated' Trump becomes top critic of law enforcement. New York Times (November 3). https://www.nytimes.com/2017/11/03/us/politics/trump-says-justice-dept-and-fbimust-do-what-is-right-and-investigate-democrats.html (Created February). Accessed 21 Feb 2018.

Baker, Peter. 2018. 'Use that word!': Trump embraces the 'nationalist' label. New York Times (October 23). https://www.nytimes.com/2018/10/23/us/politics/nationalist-president-trump.html. Accessed 18 Dec 2018

Batory, Agnes. 2016. Populists in government? Hungary's 'system of national cooperation'. Democratization 23(2):283-303.

Beinhart, Peter. 2018. Is Donald Trump a fascist? New York Times (September 11). https://www.nytimes. com/2018/09/11/books/review/jason-stanley-how-fascism-works.html. Accessed 17 Dec 2018.

Berehulak, Daniel. 2016. They are slaughtering us like animals. New York Times (December 7). https:// www.nytimes.com/interactive/2016/12/07/world/asia/rodrigo-duterte-philippines-drugs-killings. html. Accessed 21 Feb 2018.

Bermeo, Nancy. 2016. On democratic backsliding. Journal of Democracy 27(1):5-19.

Blow, Charles M. 2017. Trump savagely mauls the language. New York Times (July 17). https://www. nytimes.com/2017/07/17/opinion/donald-trump-english-language-.html. Accessed 25 Feb 2018.

Bogaards, Matthijs. 2018. De-democratization in Hungary: diffusely defective democracy. Democratization 25(8):1481-1499.

Boix, Carles. 2003. Democracy and redistribution. Cambridge: Cambridge University Press.

Booth, John A., and Mitchell A. Seligson. 2009. The legitimacy puzzle in Latin America. New York: Cambridge University Press.

Brandom, Robert B. 2000. Articulating reasons: an introduction to inferentialism. Cambridge, London: Harvard University Press.

Braswell, Matthew. 2014. Once more unto the breaching experiment: reconsidering a popular pedagogical tool. Teaching Sociology 42(2):161-167.

Bratton, Michael, Robert Mattes, and E. Gyimah-Boadi (eds.). 2005. Public opinion, democracy, and market reform in Africa. Cambridge: Cambridge University Press.

Brennan, Geoffrey. 1996. Selection and the currency of reward. In: The theory of institutional design, ed. Robert E. Goodin, 256-275. Cambridge: Cambridge University Press.

Bruni, Frank. 2018. Donald Trump's radical honesty. New York Times (January 19). https://www.nytimes. com/2018/01/19/opinion/sunday/donald-trump-lies-honesty.html. Accessed 8 Mar 2018.

Carey, John M., Gretchen Helmke, Brendan Nyhan, Mitchell Sanders, and Susan Stokes. 2019. Searching for bright lines in the trump presidency. Perspectives on Politics 17(83):699-718.

Cheibub, José Antonio. 2007. Presidentialism, parliamentarism, and democracy. Cambridge: Cambridge University Press.

Cheibub, José Antonio. 2014. The constitutional foundations of democratic consolidation. APSA-CD Comparative Democratization Newsletter 12/2: 1, 7-10.

Chenoweth, Erica. 2018. The Trump administration's adoption of the anti-revolutionary toolkit. Political Science \& Politics 51(1):19-20.

Connolly, William E. 2017. Aspirational fascism: the struggle for multifaceted democracy under Trumpism. Minneapolis: University of Minnesota Press.

Corrales, Javier. 2011. Dragon in the tropics: Hugo Chávez and the political economy of revolution in Venezuela. Washington: Brookings Institution.

Corrales, Javier. 2015. Autocratic legalism in Venezuela. Journal of Democracy 26(2):37-51.

Cruz, Leonard, and Steven Buser (eds.). 2016. A clear and present danger: narcissism in the era of Donald Trump. Asheville: Chiron.

d'Ancona, Matthew. 2017. Post-truth: the new war on truth and how to fight back. London: Ebury Press.

Diamond, Larry. 1999. Developing democracy: toward consolidation. Baltimore: Johns Hopkins University Press.

Diamond, Larry. 2015. Facing up to the democratic recession. Journal of Democracy 26(1):141-155. 
Diamond, Larry. 2016. Why democracies survive. In Search of democracy, ed. Larry Diamond, 101-117. London, New York: Routledge.

Diamond, Larry, Marc F. Plattner, and Christopher Walker (eds.). 2016. Authoritarianism goes global: the challenge to democracy. Baltimore: Johns Hopkins University Press.

Driessen, Michael D. 2012. Public religion, democracy, and islam: examining the moderation thesis in Algeria. Comparative Politics 44(2):171-189.

Erdmann, Gero. 2011. Decline of democracy: loss of quality, hybridisation and breakdown of democracy. In Regression of democracy. Special Issue 1 of Comparative Governance and Politics, ed. Gero Erdmann, Marianne Kneuer, 21-58. Wiesbaden: Springer VS.

Esen, Berk, and Sebnem Gumuscu. 2016. Rising competitive authoritarianism in Turkey. Third World Quarterly 37(9):1581-1606.

European Commission. 2017. European Commission acts to defend judicial independence in Poland. Brussels: European Commission, press release (July 25). https://ec.europa.eu/commission/presscorner/ detail/en/IP_17_2161. Accessed 3 December 2019.

Ferrín, Mónica, and Hanspeter Kriesi (eds.). 2016. How Europeans view and evaluate democracy. Oxford: Oxford University Press.

Finkel, Eugene, Adria Lawrence, and Andrew Mertha. eds. 2019. The US in comparative perspective. Newsletter of the APS A Organized Section in Comparative Politics 29/1:2-106.

Foa, Roberto Stefan, and Yascha Mounk. 2017. The signs of deconsolidation. Journal of Democracy 28(1):5-15.

Freedom House. 2018. Freedom in the world 2018: democracy in crisis. New York: Freedom House. https://freedomhouse.org/report/freedom-world/freedom-world-2018.

Frum, David. 2018. Trumpocracy: the corruption of the American republic. New York: HarperCollins.

Galston, William A. 2018. Anti-pluralism: the populist threat to liberal democracy. New Haven, London: Yale University Press.

Garfinkel, Harold. 1984. Studies in ethnomethodolgy. Cambridge: Polity.

Garfinkel, Harold. 2001. A conception of and experiments with 'trust' as a condition of concerted stable actions. In The production of reality: essays and readings on social interaction, 3rd edn., ed. Jodi O'Brien, Peter Kollock, 381-392. Thousand Oaks: Pine Force Press.

Goidel, Kirby, Keith Gaddie, and Spencer Goidel. 2019. Rigged-election rhetoric: coverage and consequences. PS Political Science \& Politics 52(2):229-238.

Gorokhovskaia, Yana. 2017. Democratic consolidation. In Oxford bibliographies in political science, ed. L. Sandy Maisel. Oxford: Oxford University Press. https://doi.org/10.1093/OBO/97801997562230224 .

Gregory, Stanford W. 1982. Accounts as assembled from breaching experiments. Symbolic Interaction 5(1):49-63.

Grimmer, Justin, and Brandon M. Stewart. 2013. Text as data: the promise and pitfalls of automatic content analysis methods for political texts. Political Analysis 21(3):267-297.

Grynbaum, Michael M. 2017. Trump calls the news media the 'enemy of the American people'. New York Times (February 17). https://www.nytimes.com/2017/02/17/business/trump-calls-the-news-mediathe-enemy-of-the-people.html. Accessed 21 Jan 2019.

Gutmann, Amy, and Dennis Thompson. 2004. Why deliberative democracy? Princeton, Oxford: Princeton University Press.

Habermas, Jürgen. 1984. The theory of communicative action. Boston: Beacon Press.

Habermas, Jürgen. 1998. Between facts and norms: contributions to a discourse theory of law and democracy. Cambridge: MIT Press.

Hale, Henry E. 2016. 25 years after the USSR: what's gone wrong? Journal of Democracy 27(3):24-35.

Havel, Václav. 1985. The power of the powerless. In The power of the powerless, ed. Steven Lukes, 23-53. Armonk: M.E. Sharpe.

Hawkins, Kirk A., and Cristóbal Rovira Kaltwasser. 2017. The ideational approach to populism. Latin American Research Review 52(4):513-528.

Higley, John, and Richard Gunther (eds.). 1992. Elites and democratic consolidation in Latin America and southern Europe. New York: Cambridge University Press.

Hirschman, Albert O. 1986. In defense of possibilism. In Rival views of market society and other recent essays, ed. Albert O. Hirschman, 171-175. Cambridge: Harvard University Press.

Hochstetler, Kathryn. 2006. Rethinking presidentialism: challenges and presidential falls in south America. Comparative Politics 38(4):401-418. 
Hulse, Carl. 2019. Trump and Senate Republicans celebrate making the courts more conservative. New York Times (November 6). https://www.nytimes.com/2019/11/06/us/trump-senate-republicanscourts.html. Accessed 11 Nov 2019.

Inglehart, Ronald, and Christian Welzel. 2005. Modernization, cultural change, and democracy: the human development sequence. Cambridge: Cambridge University Press.

Issacharoff, Samuel. 2015. Fragile democracies: contested power in the era of constitutional courts. New York: Cambridge University Press.

Judt, Tony. 2010. The memory chalet. London: Penguin Press, Mobilereference e-book.

Kahneman, Daniel. 2011. Thinking, fast and slow. London: Penguin.

Keane, John. 2004. Violence and democracy. Cambridge: Cambridge University Press.

King, Gary, Robert O. Keohane, and Sidney Verba. 1994. Designing social inquiry: scientific inference in qualitative research. Princeton: Princeton University Press.

Kingsley, Patrick. 2017. Turkey purges 4,000 more officials, and blocks Wikipedia New York Times (April 30). https://www.nytimes.com/2017/04/30/world/europe/turkey-purge-wikipedia-tv-dating-shows. html. Accessed 15 Nov 2017.

Kirshner, Alexander S. 2014. A theory of militant democracy: the ethics of combatting political extremism. New Haven, London: Yale University Press.

Klaas, Brian. 2017. The despot's apprentice: Donald Trump's attack on democracy. New York: Hot Books.

Korte, Karl-Rudolf, and Sophia Regge. 2016. Politische Kommunikation in der Vergleichenden Politikwissenschaft. In Handbuch Vergleichende Politikwissenschaft, ed. Hans-Joachim Lauth, Marianne Kneuer, and Gert Pickel, 601-614. Wiesbaden: Springer VS.

Kristof, Nicholas. 2018. Trump's threat to democracy. New York Times (January 10). https://www.nytimes. com/2018/01/10/opinion/trumps-how-democracies-die.html. Accessed 20 Jan 2019.

Krugman, Paul. 2016. How to rig an election. New York Times (November 7). https://www.nytimes.com/ 2016/11/07/opinion/how-to-rig-an-election.html. Accessed 4 Mar 2018.

Kuo, Didi. 2019. Comparing America: reflections on democracy across subfields. Perspectives on Politics 17(3):788-800.

Kuran, Timur. 1995. Private truths, public lies: the social consequences of preference falsification. Cambridge, London: Harvard University Press.

Lapuente, Victor, and Bo Rothstein. 2014. Civil war Spain versus Swedish harmony: the quality of government factor. Comparative Political Studies 47(10):1416-1441.

Lee, Bandy. 2017. The dangerous case of Donald Trump: 27 psychiatrists and mental health experts assess a president. New York: St. Martin's Press.

Leonhardt, David, and Stuart A. Thompson. 2017. Trump's Lies. New York Times (December 14, update). https://www.nytimes.com/interactive/2017/06/23/opinion/trumps-lies.html. Accessed 24 Feb 2018.

Lepenies, Philipp H. 2008. Possibilism: an approach to problem-solving derived from the life and work of Albert O. Hirschman. Development and Change 39(3):437-459.

Lessing, Benjamin. 2015. Logics of violence in criminal war. Journal of Conflict Resolution 59(8):1486-1516.

Levitsky, Steven, and James Loxton. 2013. Populism and competitive authoritarianism in the Andes. Democratization 20(1):107-136.

Levitsky, Steven, and Lucan A. Way. 2010. Competitive authoritarianism: hybrid regimes after the Cold War. New York: Cambridge University Press.

Levitsky, Steven, and Daniel Ziblatt. 2018. How democracies die. New York: Crown.

Levy, Jacob T. 2018. The weight of the words. Washington, DC: Niskanen Center (February 7). https:// niskanencenter.org/blog/the-weight-of-the-words/. Accessed 11 Mar 2018.

Lewis, Sinclair. 2014. It can't happen here. New York: Signet Classics (orig. 1935).

Lind, Michael. 2016. Donald Trump, the perfect populist. Politico Magazine (March 9). https://www. politico.com/magazine/story/2016/03/donald-trump-the-perfect-populist-213697. Accessed 19 Feb 2018.

Linz, Juan J. 1978. Crisis, breakdown, and reequilibration. Baltimore, London: Johns Hopkins University Press.

Linz, Juan J. 1990. The perils of presidentialism. Journal of Democracy 1(1):51-69.

Linz, Juan J., and Alfred C. Stepan (eds.). 1978. The breakdown of democratic regimes. 4 Vols. Baltimore: Johns Hopkins University Press.

Linz, Juan J., and Alfred C. Stepan. 1996. Problems of democratic transition and consolidation: Southern Europe, South America, and Post-Communist Europe. Baltimore and London: Johns Hopkins University Press.

Magyar, Bálint. 2016. Post-communist mafia state: the case of Hungary. Budapest: CEU Press. 
Mainwaring, Scott. 1993. Presidentialism, multipartism, and democracy: the difficult combination. Comparative Political Studies 26(2):198-228.

Mainwaring, Scott, and Aníbal Pérez-Liñán. 2013. Democracies and dictatorships in Latin America: emergence, survival, and fall. New York: Cambridge University Press.

Malka, Ariel, and Yphtach Lelkes. 2017. In a new poll, half of Republicans say they would support postponing the 2020 election if Trump proposed it. The Washington Post (August 10). https://www. washingtonpost.com/news/monkey-cage/wp/2017/08/10/in-a-new-poll-half-of-republicans-saythey-would-support-postponing-the-2020-election-if-trump-proposed-it/. Accessed 22 Feb 2018.

Martin, Jonathan, and Alexander Burns. 2016. Officials fight Donald Trump's claims of a rigged vote. New York Times (October 16). https://www.nytimes.com/2016/10/17/us/politics/donald-trump-electionrigging.html. Accessed 21 Jan 2019.

McCoy, Jennifer, Tahmina Rahman, and Murat Somer. 2018. Polarization and the global crisis of democracy: common patterns, dynamics, and pernicious consequences for democratic polities. American Behavioral Scientist 62(1):16-42.

McGann, Anthony J., Charles Anthony Smith, Michael Latner, and Alex Keena. 2016. Gerrymandering in America: the House of Representatives, the Supreme Court, and the future of popular sovereignty. Cambridge: Cambridge University Press.

McNall, Scott G., and James C. M. Johnson. 1975. The new conservatives: Ethnomethodologists, phenomenologists, and symbolic interactionists. Insurgent Sociologist, 5(4):49-65.

Merkel, Wolfgang. 2004. Embedded and defective democracies. Democratization 11(5):33-58.

Merkel, Wolfgang. 2014. Is there a crisis of democracy? Democratic Theory 1(2):11-25.

Merkel, Wolfgang. 2016. Systemwandel und -wechsel in der Vergleichenden Politikwissenschaft. In Handbuch Vergleichende Politikwissenschaft, ed. Hans-Joachim Lauth, Marianne Kneuer, and Gert Pickel, 103-122. Wiesbaden: Springer VS.

Moss, Dana M. 2018. Enter a new regime? Lessons from the study of authoritarianism for US politics. Political Science \& Politics 51(1):20-21.

Mounk, Yascha. 2018. The people vs. democracy: why our freedom is in danger and how to save it. Cambridge, London: Harvard University Press. Mobilereference e-book.

Moyn, Samuel, and David Priestland. 2017. Trump isn't a threat to our democracy. Hysteria is. New York Times (August 11). https://www.nytimes.com/2017/08/11/opinion/sunday/trump-hysteriademocracy-tyranny.html. Accessed 25 Feb 2018.

Mudde, Cas. 2010. The populist radical right: a pathological normalcy. West European Politics 33(6): 1167-1186.

Mudde, Cas. 2018. It's fashionable to say western democracies are dying. Don't buy it (yet). The Guardian (January 28). https://www.theguardian.com/commentisfree/2018/jan/28/cas-mudde-democracyfascism-trump. Accessed 7 Feb 2018.

Müller, Jan-Werner. 2017. What is populism? New York: Penguin Random House.

Munck, Gerardo L. 2006. Drawing boundaries: how to craft intermediate regime categories. In Electoral authoritarianism: the dynamics of unfree competition, ed. Andreas Schedler, 27-40. Boulder, London: Lynne Rienner.

Negretto, Gabriel L. 2006. Minority presidents and democratic performance in Latin America. Latin American Politics and Society 48(3):63-92.

O’Donnell, Guillermo. 1992. Transitions, continuities, and paradoxes. In Issues in democratic consolidation: the new south American democracies in comparative perspective, ed. Scott Mainwaring, Guillermo O’Donnell, and J. Samuel Valenzuela, 17-56. Notre Dame: University of Notre Dame Press.

O’Donnell, Guillermo. 1994. Delegative Democracy. Journal of Democracy, 5(1):55-69.

O'Donnell, Guillermo, Philippe C. Schmitter, and Laurence Whitehead (eds.). 1986. Transitions from authoritarian rule. 4 vols. Baltimore: Johns Hopkins University.

Ott, Brian L. 2017. The age of Twitter: Donald J. Trump and the politics of debasement. Critical Studies in Media Communication 34(1):59-68.

Parker, Kim. 2017. Among gun owners, NRA members have a unique set of views and experiences. Pew Research Center: Fact Tank (July 5). http://www.pewresearch.org/fact-tank/2017/07/05/among-gunowners-nra-members-have-a-unique-set-of-views-and-experiences/. Accessed 21 Feb 2018.

Pepinsky, Thomas. 2014. The institutional turn in comparative authoritarianism. British Journal of Political Science 44(3):631-653.

Pérez-Liñán, Aníbal. 2007. Presidential impeachment and the new political instability of Latin America. New York: Cambridge University Press. 
Pickel, Susanne, and Gert Pickel. 2016. Politische Kultur in der Vergleichenden Politikwissenschaft. In Handbuch Vergleichende Politikwissenschaft, ed. Hans-Joachim Lauth, Marianne Kneuer, and Gert Pickel, 541-556. Wiesbaden: Springer VS.

Posner, Eric A. 2018. The dictator's handbook, US edition. In Can it happen here? Authoritarianism in America, ed. Cass R. Sunstein, 1-17. New York: HarperCollins.

Przeworski, Adam. 2003. Why do political parties obey results of elections? In Democracy and the rule of law, ed. José María Maravall, Adam Przeworski, 114-144. Cambridge: Cambridge University Press.

Przeworski, Adam. 2005. Democracy as an equilibrium. Public Choice 123(3):253-273.

Przeworski, Adam. 2010. Democracy and the limits of self-government. Cambridge: Cambridge University Press.

Przeworski, Adam, and Fernando Limongi. 1997. Modernization: Theories and Facts. World Politics, 49(2):155-183

Przeworski, Adam, Michael E. Alvarez, José Antonio Cheibub, and Fernando Limongi. 2000. Democracy and development: political institutions and well-being in the world, 1950-1990. Cambridge: Cambridge University Press.

Putnam, Robert D., Robert Leonardi, and Raffaella Y. Nanetti. 1994. Making democracy work: civic traditions in modern Italy. Princeton: Princeton University Press.

Rathburn, Brian C. 2008. Interviewing and qualitative field methods: pragmatism and practicalities. In The oxford handbook of political methodology, ed. Janet M. Box-Steffensmeier, Henry E. Brady, and David Collier, 685-701. Oxford: Oxford University Press.

Richards, Anthony. 2001. Terrorist groups and political fronts: the IRA, Sinn Fein, the peace process and democracy. Terrorism and Political Violence 13(4):72-89.

Rovira Kaltwasser, Cristóbal. 2012. The ambivalence of populism: threat and corrective for democracy. Democratization 19(2):184-208.

Rushin, Stephen, and Griffin Sims Edwards. 2018. The effect of president Trump's election on hate crimes. Chicago: Loyola University. https://doi.org/10.2139/ssrn.3102652.

Salamé, Ghassan. 1994. Democracy without democrats? The renewal of politics in the muslim world. London: I.B. Tauris.

Savage, Charlie. 2017. Trump is rapidly reshaping the judiciary. Here's how. The New York Times (November 11). https://www.nytimes.com/2017/11/11/us/politics/trump-judiciary-appeals-courtsconservatives.html. Accessed 21 Jan 2019.

Schaffer, Frederic Charles. 2008. The hidden costs of clean election reform. Ithaca, London: Cornell University Press.

Schedler, Andreas. 1996. Anti-political-establishment parties. Party Politics 2(3):291-312.

Schedler, Andreas. 2007. Mapping contingency. In Political contingency: studying the unexpected, the accidental, and the unforeseen, ed. Ian Shapiro, Sonu Bedi, 54-78. New York: New York University Press.

Schedler, Andreas. 2013. The politics of uncertainty: sustaining and subverting electoral authoritarianism. Oxford: Oxford University Press.

Schedler, Andreas. 2019a. Do our adversaries play by the rules? The inferential role of basic democratic trust. Annual Conference, IPSA Research Committee on the Structure and Organization of Government, Mexico City, 17-18.

Schedler, Andreas. 2019b. Democratic Reciprocity. Mexico City: CIDE, unpublished typescript.

Schedler, Andreas, and Rodolfo Sarsfield. 2007. Democrats with adjectives: linking direct and indirect measures of democratic support. European Journal of Political Research 46(5):637-659.

Searle, John R. 1969. Speech acts: an essay in the philosophy of language. Cambridge: Cambridge University Press.

Selçuk, Orçun. 2016. Strong presidents and weak institutions: populism in Turkey, Venezuela and Ecuador. Southeast European and Black Sea Studies 16(4):571-589.

Shear, Michael D., and Maggie Haberman. 2016. Trump claims, with no evidence, that 'millions of people' voted illegally. New York Times (November 27). https://www.nytimes.com/2016/11/27/us/politics/ trump-adviser-steps-up-searing-attack-on-romney.html. Accessed 20 Jan 2019.

Slater, Dan. 2013. Democratic careening. World Politics 65(4):729-763.

Snyder, Timothy. 2017. On tyranny: twenty lessons from the twentieth century. New York: Tim Duggan Books.

Stevenson, Peter W. 2017. The real reason Senate Democrats are going to oppose Judge Gorsuch for the Supreme Court. The Washington Post (March 20). https://www.washingtonpost.com/news/thefix/wp/2017/03/20/the-real-reason-senate-democrats-are-going-to-oppose-judge-gorsuch-for-thesupreme-court. Accessed 18 Dec 2018. 
Sunstein, Cass R. (ed.). 2018. Can it happen here? Authoritarianism in America. New York: HarperCollins. Svolik, Milan. 2015a. Equilibrium analysis of political institutions. In Routledge handbook of comparative political institutions, ed. Jennifer Gandhi, Rubén Ruiz-Rufino, 70-83. London, New York: Routledge.

Svolik, Milan. 2015b. Which democracies will last? Coups, incumbent takeovers, and the dynamics of democratic consolidation. British Journal of Political Science 45(4):715-738.

Svolik, Milan. 2017. When polarization trumps civic virtue: partisan conflict and the subversion of democracy by incumbents. New Haven: Yale University, unpublished typescript.

Sánchez-Sibony, Omar. 2017. Classifying Ecuador's regime under Correa: a procedural approach. Journal of Politics in Latin America 9(3):121-140.

Tansey, Oisín. 2017. The fading of the anti-coup norm. Journal of Democracy 28(1):144-156.

Teorell, Jan. 2010. Determinants of democratization: Explaining regime change in the world, 1972-2006. Cambridge: Cambridge University Press.

Thompson, Mark. 2017. Enough said: what's gone wrong with the language of politics? New York: St. Martin's Griffin.

Thrush, Glenn, and Jeremy W. Peters. 2018. Charges of vote stealing in Florida portend more distrust in system for 2020. New York Times (November 18). https://www.nytimes.com/2018/11/18/us/politics/ florida-recount-voter-fraud.html. Accessed 18 Dec 2018.

Touraine, Alain. 1988. La parole et le sang: politique et société en Amérique Latine. Paris: Odile Jacob.

Tucker, Jeffrey A. 2016. Is Donald Trump a fascist? Newsweek (July 17). http://www.newsweek.com/ donald-trump-fascist-354690. Accessed 28 Feb 2018.

Tushnet, Mark V. 2004. Constitutional hardball. J. Marshall L. Review 37:523-553.

Twohey, Megan, and Michael Barbaro. 2016. Two women say Donald Trump touched them inappropriately. New York Times (October 12). https://www.nytimes.com/2016/10/13/us/politics/donald-trumpwomen.html. Accessed 8 Nov 2019.

Valenzuela, J. Samuel. 1992. Democratic consolidation in post-transitional settings: notion, process, and facilitating conditions. In Issues in democratic consolidation: the new south American democracies in comparative perspective, ed. Scott Mainwaring, Guillermo O’Donnell, and J. Samuel Valenzuela, 57-104. Notre Dame: University of Notre Dame Press.

Varieties of Democracy. 2017. Democracy at dusk? V-Dem annual report 2017. Gothenburg: University of Gothenburg.

Waldner, David, and Ellen Lust. 2018. Unwelcome change: coming to terms with democratic backsliding. Annual Review of Political Science 21:93-113.

Weyland, Kurt. 2013. Latin America's authoritarian drift: the threat from the populist left. Journal of Democracy 24(3):18-32.

Willingham, Emily. 2016. Why does Donald Trump lie so much? Forbes (September 27). https:/www. forbes.com/sites/emilywillingham/2016/09/27/why-does-donald-trump-lie-so-much/\#708346c33788. Accessed 25 Feb 2018.

Winch, Peter. 1958. The idea of a social science and its relation to philosophy. London: Routledge.

Wines, Michael, and Maggie Haberman. 2018. Trump closes voter fraud panel that bickered more than it revealed. New York Times (January 4). https:/www.nytimes.com/2018/01/04/us/voting-fraudcommission.html. Accessed 20 Jan 2019.

Winters, Jeffrey A. 2011. Oligarchy. New York: Cambridge University Press.

Wodak, Ruth, and Bernhard Forchtner (eds.). 2018. The Routledge handbook of language and politics. London, New York: Routledge. 